ISSN 0258-7122

Bangladesh J. Agril. Res. 40(4): 521-528, December 2015

\title{
SOWING TIME AND VARIETAL PERFORMANCE OF WHEAT AT HIGHER ELEVATION IN HILL ENVIRONMENT AT KHAGRACHARI
}

\author{
M. AtAur RAHMAN ${ }^{1}$, M. MOHABbatUllah ${ }^{2}$, C. K. DAS ${ }^{3}$ \\ U. K. SARKER ${ }^{4}$ AND S. M. M. ALAM ${ }^{5}$
}

\begin{abstract}
The field experiment was conducted at the Hill Agricultural Research Station, BARI, Khagrachari for the two consecutive years (2009-10 and 2010-11) to find out the wheat variety suitable for hilly environment and investigate the interaction of sowing dates and varieties to recommend the promising variety with proper sowing time. The experiment was laid out in split-plot design with three replications where three dates of sowing (Nov. 20, Nov. 30 and Dec. 10) were assigned in the main plots and five modern wheat varieties (Shatabdi, Sufi, Sourav, Bijoy and Prodip) were tested in the sub-plots. The yield responses of wheat varieties during the two years showed that there were significant varietal differences under the experimental soil and environmental conditions. The variety Bijoy gave maximum grain yield closely followed by Sourav in both years. Shatabdi produced higher yield under early sowing (Nov. 20) but yield was decreased due to late sowing (Dec. 10). Initially the plant population and finally spikes $/ \mathrm{m}^{2}$ were affected by late sowing that caused less yield in Shatabdi. The mean yield of all varieties pulled over the sowing time indicated that wheat yield was not affected due to delay sowing up to $10^{\text {th }}$ December. The experimental result demonstrated that Shatabdi could be recommended only for early sowing whereas Bijoy and Sourav could be recommended both for early and late sowing under the experimental soil and environmental conditions at hilly region of Khagrachari.
\end{abstract}

Keywords: Wheat variety, Sowing time, Adaptation, Higher elevation.

\section{Introduction}

Commercial farming of high value crops in traditional wheat growing regions and high crop competition in limited arable land caused gradual reduction of wheat areas in Bangladesh for the last decade. Wheat area and production were 0.77 million ha and 1.67 million tons, respectively, in 2000-01 whereas the area and production declined to 0.36 million ha and 0.98 million tons in 2011-12 (BBS, 2012). At present the national consumption of wheat is about four fold higher than annual domestic production and thus to meet the national demand a lion share is being imported at the cost of valuable foreign currencies and this food dependence is vulnerable for our national food security. Therefore, due attention is needed to increase the domestic production of wheat by expanding its

\footnotetext{
${ }^{1}$ Principal Scientific Officer, Regional Wheat Research Centre, Bangladesh Agricultural Research Institute (BARI), Gazipur, ${ }^{2}$ Chief Scientific Officer, Hill Agricultural Research Centre, BARI, Khagrachari, ${ }^{3}$ Assistant Professor, Sylhet Agricultural University, Sylhet, ${ }^{4}$ Assistant Professor, Bangladesh Agricultural University (BAU), Mymensing, ${ }^{5}$ Scientific Officer, Wheat Research Centre, BARI, Dinajpur, Bangladesh.
} 
cultivation in the non-traditional areas of the country where cropping intensity is low and there are scopes of wheat expansion. The Hill Tract regions comprises about one tenth of the country consisting $75 \%$ upland (hill), $20 \%$ undulating bumpy land and 5\% valley plain land. A huge undulating bumpy land and the valleys remain fallow in the winter due to lack of irrigation water required for boro rice cultivation. Water requirement of wheat is less than one-fourth of that of rice, thus most of the areas can be brought under wheat cultivation with the limited water resource available in those regions. The physical and environmental conditions of the hill regions are different from that of conventional wheat growing areas of the country. Much works have been done to improve wheat yield through manipulating sowing time (Hossain et al., 2009) and introducing new varieties (Rahman et al., 2013, Barma et al., 1994). The sowing date of wheat is considered as most important factor limiting the wheat yield and it is reported that wheat yield decreased at the rate of $1.3 \%$ per day delay sowing after $30^{\text {th }}$ November under the short spell of winter in Bangladesh (Ahmed et al., 1998). The pattern and spell of winter at the hill is different and, therefore, sowing time of wheat may be adjusted to explore the environmental benefit. Also there may have differences in relation to varietal adoption in hill regions that need to be explored for promoting the promising varieties in hill region. Several reports suggested that the yield performance of wheat varieties varied with soil type (Rahman et al., 2013, Tang et al., 2003), air temperatures (Rahman et al., 2005), and management conditions (Rahman et al., 2002; Timsina and Cornor, 2001). There may have varietal difference in response to change in elevation and environmental condition at the hill region. The wheat varieties which produce higher yield at the higher elevation of Khagrachuri might be considered as adaptable in hill regions. Therefore, the present experiment was aimed at investigating the varietal differences in response to higher elevation and to identify the appropriate sowing time preferable for that location with the final goal of wheat expansion in non-traditional hill valleys in Bangladesh.

\section{Materials and Method}

The field experiment was conducted in the valley land of Hill Agricultural Research Station, Khagrachari for the two consecutive years of 2009-10 and 2010-11. The experimental field is about 520 meters above the sea level and night temperature is cooler and the spell of winter is wider than the central part of Bangladesh. The annual temperature varies from $11.5^{\circ}$ to $34.0^{\circ} \mathrm{C}$ with a mean of $17.5^{\circ}$ to $24.0^{\circ} \mathrm{C}$ during the wheat growing period of December to March. Weekly mean of minimum and maximum temperature, relative humidity and rainfall for the wheat growing period in 2010-11 are presented in Fig. 1. The soils of experimental field was strongly acidic ( $\mathrm{pH}$ 4.8-5.1) with higher levels of $\mathrm{Fe}$, $\mathrm{Al}$ and $\mathrm{Mn}$ in surface soil $(0-15 \mathrm{~cm}$ depth) and deficit in several essential plant nutrients including nitrogen (Total $\mathrm{N}=0.08-0.09 \%)$, phosphorus $(\mathrm{Olsen} \mathrm{P}=5.5$ $6.5 \mathrm{ppm})$ and potassium $(\mathrm{K}=0.17-0.21 \mathrm{meq} / 100 \mathrm{~g})$. The soil was rich in sulfur and zinc content but available boron content was critical to low. The physical and 
chemical properties of the soil prior to conducting the experiment are presented in Table 1. The experiment was laid-out in such a soil in split-plot design with three replications where three sowing dates (November 20, November 30 and December 10) were assigned in the main plots and five wheat varieties namely Shatabdi, Sufi, Sourav, Bijoy and Prodip were tested in the sub plots. The size of each subplot was $5 \mathrm{~m} \mathrm{X} 2 \mathrm{~m}$. Fertilizers at the rates of $100 \mathrm{~kg} \mathrm{~N}, 30 \mathrm{~kg} \mathrm{P}, 50 \mathrm{~kg}$ $\mathrm{K}, 20 \mathrm{~kg} \mathrm{~S}^{-1}$ and $2 \mathrm{~kg} \mathrm{~B} \mathrm{ha}^{-1}$ were applied as urea, triple super phosphate, muriate of potash, gypsum and boric acid, respectively. All fertilizers including two-thirds of urea were uniformly applied in the field during final land preparation. The rest of urea was top dressed at the crown root initiation (CRI) stage at 21 days after sowing (DAS). The crop was irrigated thrice to bring the soil moisture near to field capacity during CRI, booting and grain-filling stages. Weeds were controlled once at 35 DAS manually by hand weeding. After maturity crops were harvested duly, sun-dried and threshed on sub-plot basis. Then the grains were dried in the atmosphere and grain moisture content was measured to convert the grain yield to $\mathrm{tha}^{-1}$ at $12 \%$ moisture content. Before harvest ten plants were sampled from each plot to calculate plant height, spikelet/spike, grains/spike and 1000-grains weight. Initial plant population and spikes $/ \mathrm{m}^{2}$ were also counted at $20 \mathrm{DAS}$ and at maturity following standard method. All the data were statistically analyzed and the mean value was tested by the least significant difference (LSD) at 5\% level of significance.

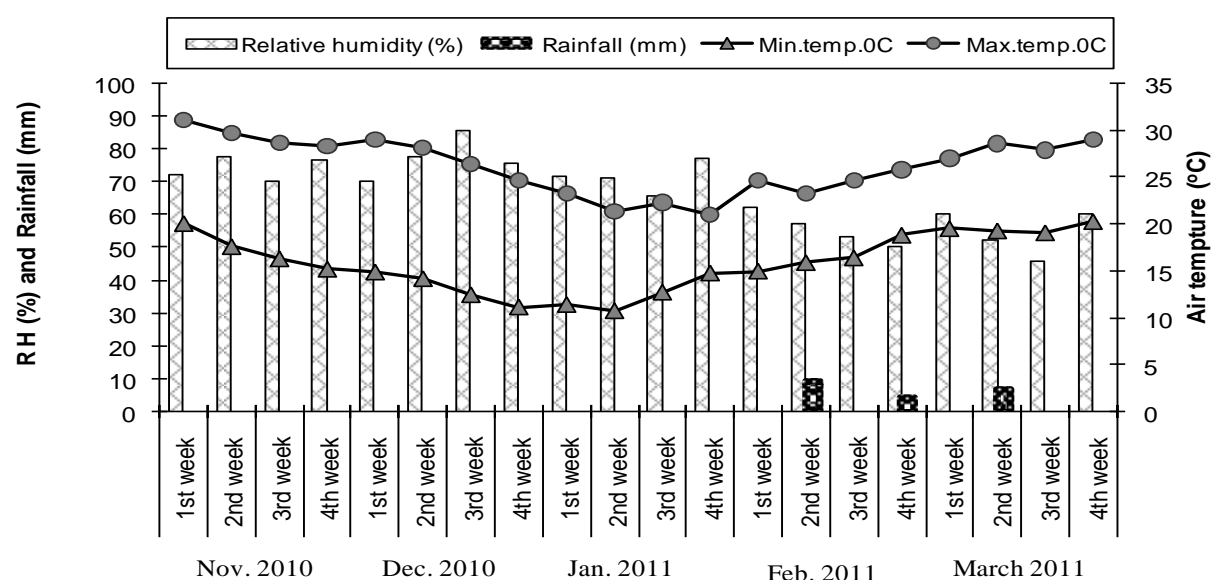

Fig. 1. Weekly average maximum and minimum air temperature, rainfall and relative humidity (RH) during the cropping period of 2010-11 at Khagrachuri.

\section{Results and Discussion}

\section{a) Effect of sowing time}

Different sowing dates had statistically similar effect on grain yield and all the yield components of wheat including plant height in both the experimental years 
(Tables 2 and 3) with the exception of initial plant population (IPP) at 20 DAS in 2009-10. IPP was the maximum in the sowing date of Nov 20, followed by Nov 30 and Dec 10 in the years of 2009-10 but this advantage of higher plant population finally failed to contribute higher spikes $/ \mathrm{m}^{2}$ or grain yield. Thousand grain weight (TGW) is considered as most important yield component affected by late sowing induced heat stress. TGW was declined from 47.0 to $46.1 \mathrm{~g}$ and from 47.7 to $46.5 \mathrm{~g}$ due to 20 days delay sowing from November 20 to December 10 , during the years of 2009-10 and 2010-11, respectively, which resulted in statistically similar wheat yield. The yield response of wheat to sowing dates had been studied intensively in Bangladesh conditions and several reports suggested that late sowing caused significant yield loss by reducing grain size expressed as TGW and thus yield drastically declines under late sowing. Late sowing caused the significant reduction in TGW (Rahman et al., 2005); reduced number of spikes $/ \mathrm{m}^{2}$ (Rahman et al., 2009) thus resulted drastic yield reduction in wheat. Ahmed and Meisner (1996) reported that under Bangladesh condition wheat yield decreased at the rate of $1.3 \%$ per day delay after $30^{\text {th }}$ November that was due to decreasing TGW. In present study, such an adverse effect of late sowing was not noticed. Our experimental plants were also exposed to relatively higher day temperature from the end of February but yet the night temperature was cooler as indicated by average of minimum temperature (Fig. 1). Thus grain size measured by TGW was similar for different sowing dates. Spikes $/ \mathrm{m}^{2}$ was also statistically similar thus different sowing dates contributed to statistically similar yield. The result indicated that wheat sowing until $10^{\text {th }}$ December could be recommended for the experimental soil and environmental conditions without yield loss. Jhum cultivation is the common practice in the hills that are usually planted at the beginning of rainy season. At the base of the hills, in the valleys the major cropping system are T. aman-Fallow-Fallow and T. aman-BoroFallow. Most of the T. aman rice varieties are long duration local varieties which are harvested in early December. Under such a condition, the experimental results are encouraging that wheat can be sown until $10^{\text {th }}$ December without significant yield loss.

\section{b) Response of variety}

All the varieties tested in the present experiment were spring type semi-dwarf and its height and number of spikelet/spike were statistically similar in both the years but there were significant variations in several other traits like initial plant population, spikes $/ \mathrm{m}^{2}$, grains/spike, thousand grain weight and grain yield (Tables 2 and 3). IPP at 20 DAS and number of spikes $/ \mathrm{m}^{2}$ during harvest was the maximum in Bijoy followed by Sourav in 2009-10 (Table 2). During 2010-11 the same variety (Bijoy) produced highest IPP and spikes $/ \mathrm{m}^{2}$ which were statistically similar to other varieties but higher than Prodip (Table 3). Bijoy also scored second highest number of grains/spike next to Sufi and higher TGW similar to Prodip in both the years. All those facts ultimately resulted in the maximum grain yield of Bijoy similar to Sourav but higher than other varieties. Both variety Bijoy and Sourav were released earlier compared to Shatabdi and Prodip, and the yield 
performance of latter two varieties was relatively higher (but not significant) than the former two varieties under the other areas in Bangladesh (WRC Annual report 2011). But in present experimental condition at Khagrachari, Bijoy and Saurav resulted in higher yield compared to other varieties. Prodip produced the least number of spikes $/ \mathrm{m}^{2}$ whereas other four varieties produced statistically similar number of spikes $/ \mathrm{m}^{2}$ for both the years. Initial plant population at 20 DAS was the minimum in Prodip which indicated that germination and stand establishment was seriously affected in Prodip resulting comparatively less number of spikes $/ \mathrm{m}^{2}$ which finally contributed to poor grain yield of the variety compared to other varieties. Number of grains/spike was the highest in Sufi followed by Bijoy and Saurav. However, this advantage of higher grains/spike of Sufi could not result in higher yield due to its smaller grain size as indicated by the least TGW. Thousand grain weight was the maximum in Prodip which was statistically similar to all other varieties except Sufi. Varietal difference in response to location $\mathrm{x}$ genotype interaction and drought had been reported by Barma et al. (1994) and Fisher and Maurer (1978). Rahman et al. (2013) reported that Bijoy gave higher yield and more adaptable under acidic soil condition in Sylhet. Present experimental result demonstrated that Bijoy and Sourav are preferable under higher elevation hilly environment at Khagrachari.

Table 1a. Physical and chemical properties of initial soil collected from surface layer $(0-15 \mathrm{~cm})$.

\begin{tabular}{c|c|c|c|c|c|c}
\hline \multirow{2}{*}{$\begin{array}{c}\text { Physical } \\
\text { Properties }\end{array}$} & $\begin{array}{c}\text { Bulk } \\
\text { density } \\
(\mathrm{g} \mathrm{cm}-3)\end{array}$ & $\begin{array}{c}\text { Particle } \\
\text { density } \\
(\mathrm{g} \mathrm{cm}-3)\end{array}$ & $\begin{array}{c}\text { Porosity } \\
(\%)\end{array}$ & $\begin{array}{c}\text { Soil moisture } \\
\text { at sowing } \\
(\%)\end{array}$ & $\begin{array}{c}\text { Soil moisture at } \\
\text { field capacity } \\
(\%)\end{array}$ & $\begin{array}{c}\text { Textural } \\
\text { class }\end{array}$ \\
\cline { 2 - 7 } & 1.42 & 2.48 & 42.74 & 21.04 & 28.12 & $\begin{array}{c}\text { Clay } \\
\text { Loam }\end{array}$ \\
\hline
\end{tabular}

Table 1b. Chemical properties of initial soil collected from surface layer $(0-15 \mathrm{~cm})$.

\begin{tabular}{l|c|c|c|c|c|c|c|c|c|c|c|c|c}
\hline $\begin{array}{l}\text { Chemical } \\
\text { properties }\end{array}$ & $\mathrm{pH}$ & $\begin{array}{c}\mathrm{OM} \\
(\%)\end{array}$ & $\begin{array}{c}\text { Total } \\
\mathrm{N}(\%)\end{array}$ & $\mathrm{P}$ & $\mathrm{S}$ & $\mathrm{B}$ & $\mathrm{Zn}$ & $\mathrm{Cu}$ & $\mathrm{Fe}$ & $\mathrm{Mn}$ & $\mathrm{K}$ & $\mathrm{Ca}$ & $\mathrm{Mg}$ \\
\hline $2009-10$ & 4.8 & 1.12 & 0.09 & 5.1 & 36 & 0.18 & 3.8 & 3.1 & 104 & 16 & 0.17 & 4.7 & 2.1 \\
$2010-11$ & 5.1 & 0.98 & 0.08 & 6.5 & 41 & 0.16 & 4.1 & 3.1 & 97 & 16 & 0.21 & 5.1 & 2.0 \\
\multicolumn{2}{l}{ Critical level -} & - & - & 7 & 14 & 0.20 & 2.0 & 1.0 & 10.0 & 5.0 & 0.20 & 2.0 & 0.8 \\
\hline
\end{tabular}

\section{c) Interaction effect of sowing time and variety}

Initial plant population, spikes $/ \mathrm{m}^{2}$ and grain yield of wheat were significantly influenced by the interaction of sowing time and variety (Table 2 and 3). Shatabdi gave the highest yield under the first sowing date and the yield was statistically similar to Bijoy and Sourav in both the years. The yield of Shatabdi was significantly declined due to late sowing on December 10 as compared to sowing on November 20. Similar trend of higher yield reduction with sowing 
Table 2. Yield component and agronomic characters of wheat as influenced by dates of sowing and variety at Khagrachuri in 2009-10.

\begin{tabular}{|c|c|c|c|c|c|c|c|c|}
\hline \multicolumn{2}{|c|}{ Treatment } & \multirow{2}{*}{$\begin{array}{c}\text { IPP at } \\
20 \mathrm{DAS}\end{array}$} & \multirow{2}{*}{$\begin{array}{c}\text { Plant } \\
\text { ht. } \\
(\mathrm{cm})\end{array}$} & \multirow{2}{*}{$\begin{array}{c}\text { Spikes } \\
\mathrm{m}^{-2}\end{array}$} & \multirow{2}{*}{$\begin{array}{c}\text { Spikelet } \\
\text { spike }^{-1}\end{array}$} & \multirow{2}{*}{$\begin{array}{l}\text { Grains } \\
\text { spike }^{-1}\end{array}$} & \multirow{2}{*}{$\begin{array}{c}\text { TGW } \\
(\mathrm{g})\end{array}$} & \multirow{2}{*}{$\begin{array}{l}\text { Grain yield } \\
\text { (t/ha) }\end{array}$} \\
\hline Sowing date & Variety & & & & & & & \\
\hline \multirow[t]{5}{*}{ Nov. 20} & Shatabdi & 218.6 & 96.2 & 335.7 & 17.7 & 44.2 & 48.7 & 3.85 \\
\hline & Sufi & 197.2 & 93.5 & 302.7 & 17.5 & 47.7 & 37.5 & 3.04 \\
\hline & Sourav & 198.6 & 93.8 & 346.8 & 17.7 & 47.9 & 46.8 & 3.55 \\
\hline & Bijoy & 222.3 & 96.8 & 360.1 & 18.5 & 48.7 & 49.8 & 3.80 \\
\hline & Prodip & 205.7 & 88.9 & 248.7 & 16.5 & 39.2 & 52.1 & 3.32 \\
\hline \multirow[t]{5}{*}{ Nov. 30} & Shatabdi & 178.0 & 95.7 & 298.5 & 17.1 & 45.8 & 46.8 & 3.25 \\
\hline & Sufi & 181.3 & 93.2 & 312.8 & 16.9 & 49.5 & 36.8 & 3.05 \\
\hline & Sourav & 214.8 & 94.5 & 325.5 & 17.3 & 47.8 & 45.8 & 3.82 \\
\hline & Bijoy & 213.5 & 98.4 & 364.5 & 18.3 & 50.2 & 50.2 & 4.05 \\
\hline & Prodip & 180.2 & 87.1 & 258.7 & 16.7 & 41.2 & 51.2 & 3.20 \\
\hline \multirow[t]{5}{*}{ Dec. 10} & Shatabdi & 167.5 & 93.1 & 265.0 & 16.9 & 41.5 & 46.7 & 3.05 \\
\hline & Sufi & 188.4 & 90.8 & 321.8 & 17.4 & 47.7 & 36.5 & 2.88 \\
\hline & Sourav & 196.2 & 92.8 & 316.5 & 17.5 & 45.9 & 46.7 & 3.74 \\
\hline & Bijoy & 215.6 & 95.8 & 355.8 & 18.1 & 47.5 & 49.8 & 3.88 \\
\hline & Prodip & 166.6 & 88.9 & 247.8 & 16.8 & 38.7 & 49.5 & 3.02 \\
\hline \multicolumn{9}{|c|}{ Mean of Sowing dates } \\
\hline Nov. 20 & & 208.4 & 93.8 & 318.8 & 17.6 & 45.5 & 47.0 & 3.51 \\
\hline Nov. 30 & & 193.5 & 93.8 & 312.0 & 17.3 & 46.9 & 46.2 & 3.46 \\
\hline Dec. 10 & & 186.9 & 92.3 & 301.4 & 17.3 & 44.8 & 45.8 & 3.32 \\
\hline \multicolumn{9}{|c|}{ Mean of variety } \\
\hline & Shatabdi & 188.0 & 95.0 & 299.7 & 17.2 & 43.8 & 47.4 & 3.38 \\
\hline & Sufi & 189.0 & 93.2 & 314.4 & 17.3 & 48.3 & 36.9 & 2.98 \\
\hline & Sourav & 203.2 & 93.5 & 331.0 & 17.6 & 46.6 & 46.8 & 3.70 \\
\hline & Bijoy & 217.1 & 97.0 & 360.1 & 18.3 & 48.7 & 49.9 & 3.91 \\
\hline & Prodip & 184.2 & 88.3 & 251.7 & 16.7 & 39.7 & 50.9 & 3.18 \\
\hline \multirow{3}{*}{$\operatorname{LSD}_{(0.05)}$} & $\begin{array}{l}\text { Sowing } \\
\text { dates }\end{array}$ & 18.4 & NS & NS & NS & NS & NS & NS \\
\hline & Variety & 21.0 & 7.5 & 32.4 & NS & 4.0 & 4.3 & 0.36 \\
\hline & Interaction & 20.1 & NS & 28.5 & NS & NS & NS & 0.33 \\
\hline CV (\%) & & 8.4 & 7.5 & 8.8 & 6.4 & 10.6 & 5.8 & 10.1 \\
\hline
\end{tabular}

date was found in Shatabdi followed by Prodip in both the years. The yield reduction of Shatabdi and and Prodip in response to sowing date was mainly associated with initial plant population and spikes $/ \mathrm{m} 2$ as both the parameters were significantly affected by the interaction of variety and sowing dates. On the contrary, Bijoy produced statistically similar yield like Shatabdi under first sowing date and under $2^{\text {nd }}$ and 3rd sowing dates the yield of Bijoy was higher 
than Shatabdi. However, Sourav performed second highest yield similar to Bijoy on $2^{\text {nd }}$ and $3^{\text {rd }}$ sowing in both the years. The yield variation due to sowing dates was the least in Bijoy following Saurav. The result indicated that both Bijoy and Sourav had the potentials to produce higher and stable yield over the sowing dates whereas Shatabdi was preferable only for early sowing under the experimental soil and environmental conditions.

Table 3. Yield component and agronomic characters of wheat as influenced by dates of sowing and variety at Khagrachuri in 2010-11.

\begin{tabular}{|c|c|c|c|c|c|c|c|c|}
\hline \multicolumn{2}{|c|}{ Treatment } & \multirow{2}{*}{$\begin{array}{c}\text { IPP at } \\
20 \mathrm{DAS}\end{array}$} & \multirow{2}{*}{$\begin{array}{c}\text { Plant } \\
\text { ht. } \\
(\mathrm{cm})\end{array}$} & \multirow{2}{*}{$\begin{array}{c}\text { Spikes } \\
\mathrm{m}^{-2}\end{array}$} & \multirow{2}{*}{$\begin{array}{c}\text { Spikelet } \\
\text { spike }^{-1}\end{array}$} & \multirow{2}{*}{$\begin{array}{l}\text { Grains } \\
\text { spike }^{-1}\end{array}$} & \multirow{2}{*}{$\begin{array}{c}\text { TGW } \\
(\mathrm{g})\end{array}$} & \multirow{2}{*}{$\begin{array}{l}\text { Grain } \\
\text { yield } \\
\text { (t/ha) }\end{array}$} \\
\hline Sowing date & Variety & & & & & & & \\
\hline \multirow[t]{5}{*}{ Nov. 20} & Shatabdi & 212.5 & 97.8 & 320.5 & 17.7 & 44.2 & 49.8 & 4.18 \\
\hline & Sufi & 206.0 & 97.3 & 308.7 & 17.3 & 49.7 & 40.1 & 3.21 \\
\hline & Sourav & 195.8 & 97.7 & 312.0 & 17.9 & 44.8 & 47.4 & 3.88 \\
\hline & Bijoy & 202.8 & 101.8 & 338.4 & 18.3 & 47.5 & 48.9 & 4.10 \\
\hline & Prodip & 168.5 & 96.8 & 285.5 & 17.3 & 38.8 & 52.5 & 3.64 \\
\hline \multirow[t]{5}{*}{ Nov. 30} & Shatabdi & 193.4 & 98.5 & 312.5 & 17.4 & 41.6 & 49.3 & 3.81 \\
\hline & Sufi & 186.3 & 97.3 & 317.8 & 17.3 & 49.8 & 38.9 & 3.18 \\
\hline & Sourav & 185.7 & 97.8 & 302.0 & 17.5 & 42.4 & 46.6 & 4.02 \\
\hline & Bijoy & 212.7 & 101.2 & 338.4 & 17.9 & 45.5 & 48.7 & 4.28 \\
\hline & Prodip & 156.0 & 97.6 & 278.3 & 16.7 & 37.8 & 51.8 & 3.52 \\
\hline \multirow[t]{5}{*}{ Dec. 10} & Shatabdi & 172.0 & 96.8 & 278.5 & 17.1 & 40.1 & 47.5 & 3.46 \\
\hline & Sufi & 197.8 & 96.4 & 308.2 & 17.3 & 48.9 & 37.3 & 3.08 \\
\hline & Sourav & 192.6 & 97.8 & 312.5 & 17.5 & 44.2 & 48.1 & 3.94 \\
\hline & Bijoy & 198.5 & 99.8 & 318.5 & 18.1 & 46.1 & 49.4 & 4.20 \\
\hline & Prodip & 161.2 & 95.8 & 266.2 & 17.0 & 36.7 & 50.2 & 3.38 \\
\hline \multicolumn{9}{|c|}{ Mean of Sowing dates } \\
\hline Nov. 20 & & 197.1 & 98.3 & 313.0 & 17.7 & 45.0 & 47.7 & 3.80 \\
\hline Nov. 30 & & 186.4 & 98.5 & 309.8 & 17.4 & 43.4 & 47.1 & 3.77 \\
\hline Dec. 10 & & 184.8 & 97.3 & 296.8 & 17.4 & 43.2 & 46.5 & 3.61 \\
\hline \multicolumn{9}{|c|}{ Mean of variety } \\
\hline & Shatabdi & 192.1 & 97.7 & 303.8 & 17.4 & 42.0 & 48.9 & 3.78 \\
\hline & Sufi & 197.0 & 97.0 & 311.6 & 17.3 & 49.5 & 38.8 & 3.16 \\
\hline & Sourav & 191.5 & 97.8 & 308.8 & 17.6 & 43.8 & 47.4 & 3.95 \\
\hline & Bijoy & 204.7 & 101.0 & 331.8 & 18.1 & 46.4 & 49.0 & 4.19 \\
\hline & Prodip & 161.8 & 96.7 & 276.7 & 17.0 & 37.7 & 51.5 & 3.51 \\
\hline \multirow[t]{3}{*}{$\operatorname{LSD}_{(0.05)}$} & $\begin{array}{l}\text { Sowing } \\
\text { dates }\end{array}$ & NS & NS & NS & NS & NS & 3.9 & NS \\
\hline & Variety & 16.1 & 7.1 & 28.4 & NS & 3.9 & 4.2 & 0.37 \\
\hline & Interaction & 18.2 & NS & 26.2 & NS & NS & NS & 0.34 \\
\hline CV (\%) & & 8.9 & 6.2 & 7.4 & 5.8 & 9.1 & 6.1 & 7.6 \\
\hline
\end{tabular}




\section{Conclusion}

The national average yield of wheat was $2.38 \mathrm{t} / \mathrm{ha}$ and $2.45 \mathrm{t} / \mathrm{ha}$ during the experimental year of 2009-10 and 2010-11, respectively. Under such a low national average yield, the yield performance of wheat varieties under experimental non-traditional hilly environment was found very encouraging. The wheat variety Bijoy and Sourav could be sown until $10^{\text {th }}$ December without yield loss. The farmers in those areas prefer to cultivate long duration local rice which ripen lately in early December and boro rice is not suitable due to lack of irrigation water. Under such a condition the wheat variety Bijoy and Sourav could be recommended to promote in hill regions to improve the productivity.

\section{Referecce}

Anonymous. 2011. Annual Research Report for 20010-11. Wheat Research Centre, Bangladesh Agricultural Researtch Institute,Nashipur, Dinajpur, 211 P.

Ahmed, S. M. and C. A. Meisner. 1996. Wheat Research and Development in Bangladesh. Bangladesh- Australia wheat improvement project and CIMMYTBangladesh., Dkaka, 167 Pp.

Barma, N. C. D., A. B. Siddique, Z. I. Sarker, M. A. Samad \& M. A. Razzaque. 1994. Genotype $\times$ Location interaction and stability analysis in wheat. Bangladesh J. of Plant Breed. \& Genet. 7(1): 31-35.

BBS, 2012. Bangladesh Bureau of Statistics, Statistical Yearbook of Bangladesh, Statistics Division, Ministry of Planning, Government of Bangladesh.

Fisher, R. A. and R. Maurer, 1978. Drought resistance in spring wheat cultivars. I. Grain yield responses. Aust. J. Agric. Res. 29: 897-907.

Rahman, M. A., M. A. Sufian, M. Saifuzzaman, and J. Chikushi. 2002. Nitrogen management in rice-wheat alternating cropping system and wheat genotype identification preferable for surface seeding condition. Journal Fac. Agr. Kyushu Univ. 46 (2): 295-300.

Rahman, M. A., J. Chikushi, S. Yoshida, H. Yahata, and E. Yasunsga. 2005. Effect of high air temperature on grain growth and yields of wheat genotypes differing in heat tolerance. J. Agric Meteor. 60(5): 605-608.

Rahman, M. A., J. Chikushi, J. G. Lauren, J. M. Duxbury, C. A. Meisner, and E. Yasunaga. 2005. Chemical control of soil environment by lime and nutrients to improve the productivity of acidic alluvial soils under rice-wheat cropping system. Environ. Control in Biology 43(4): 259-266.

Rahman, M. A., J. Chikushi, S. Yoshida and A. J. M. S. Karim. 2009. Growth and yield components of wheat genotypes exposed to high temperature stress under control environment. Bangladesh J. Agri. Res. 34(3): 361-372.

Rahman, M. A., N. C. D. Barma, M. H. Sarker, M. M. R. Sarker and M. I. Nazrul. 2013. Adaptability of wheat varieties in strongly acidic soils of Sylhet. Bangladesh J. Agric. Res. 38(1): 97-104.

Rahman, M. M., A. Hossain, M. A. Hakim, M. R. Kabir and M. M. R. Shah. 2009. Performance of wheat genotypes under optimum and late sowing conditions. Int. J. Sustain. Crop Prod. 4(6): 34-39.

Tang, C., Z. Rengel, E. Diatloff and C. Gazey. 2003. Response wheat and barley to liming on sandy soil with subsoil acidity. Field Crops Res. 80: 235-244.

Timsina, J. and D. J. Cornor. 2001. Productivity and management of rice-wheat cropping systems: Issues and challenges. Field Crops Res. 69: 93-132. 